\section{Er pasientarbeid og kommunikasjon utenfor sykehuset noe helt for seg selv?}

Halvor Nordby

Etikk og kommunikasjon i prehospitalt medisinsk arbeid

173 s, ill. Oslo: Gyldendal Akademisk, 2010. Pris NOK 349

ISBN 978-82-05-40000-9

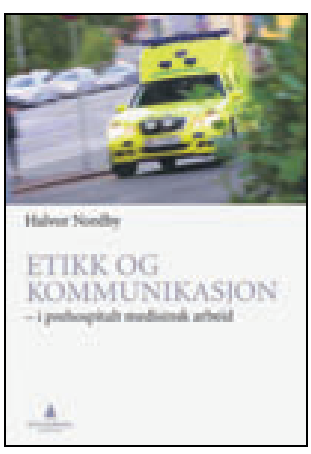

Det er ingen tvil om at kommunikasjon mellom pasienter og helsearbeidere er noe som kan volde mange problemer og unødig lidelse for begge parter. Nesten alle klager og avviksmeldinger har kommunikasjon som en medvirkende årsak,

og plusser man på etikk, er nok omfanget enda større. Således er det interessant at det har kommet en ny lærebok i etikk og kommunikasjon. Forfatteren er filosof, tilknyttet Høgskolen i Lillehammers videreutdanning for ambulansepersonell (paramedic-studiet). Målgruppen er derfor naturlig nok primært ambulansepersonell, og forfatteren baserer seg mye på undersøkelser og erfaringer fra denne utdanningen. I tillegg har han hospitert ved ambulansetjenester og i AMK.

Forfatteren tar opp etiske metodeverktøy og teorier, kommunikasjon og kultur samt litt juss. Hvert kapitel har eksempler og avsluttes med en grei samling studiespørsmål. Formatet er behagelig, og trykkvaliteten er god, men det er sparsomt med illustrasjoner og tabeller. Språkføringen virker også til tider litt unaturlig og unødig teoretisk. Likeledes ville undertegnede ha foretrukket referanser etter hvert kapittel. Referansene er for øvrig ikke angitt med sidetall.

Det er ingen tvil om behovet for å ta opp disse tema i forbindelse med ambulansearbeiderutdanningen, men det er problematisk at det ifølge boken kan virke som om det nesten bare er denne yrkesgruppen som driver prehospital akuttmedisin i Norge. Mange av forfatterens diskusjoner synes faktisk å se bort fra det faktum at ambulansearbeiderne er en del av en kjede, og at de derfor ikke må se på seg selv som en isolert del av helsesystemet. Et økende problem i dag er at kommunehelsetjenesten og primærlegene distanseres fra ambulansetjenesten ved at ambulansepersonell heller vil agere på egenhånd enn å involvere legevaktlegen. Dette er en ugunstig utvikling, og en mer kompetent ambulansetjeneste må suppleres med mer kompetente, lokale akuttmedisinske team. Ambulansearbeideren skal heller ikke primært stille dia- gnoser, men snarere identifisere tegn på organsvikt og behov for nødvendige tiltak. Omsorgselementet må heller ikke overses. Det kjøres langt flere «grønne» oppdrag enn «bloddryppende» akuttoppdrag der sekundene teller!

Historier fra «virkeligheten» er alltid bra, spesielt i en lærebok om etikk og kommunikasjon. Likevel kjenner ikke anmelderen seg alltid igjen i den virkeligheten som beskrives. Når forfatteren i et eksempel (s. 146) beskriver hvordan en lege skal forklare seg for ambulansepersonell i forbindelse med administrering av morfin, er ansvarsforholdet nesten snudd på hodet. Det er synd at ikke leseren blir henvist til legemiddelforskriften. Det er både mulig og nødvendig å konferere med AMK og AMK-lege eller legevaktslege. Ambulansepersonell er ikke primært solospillere som skal fungere helt alene. De er del av et system. Der forfatteren glimter til, er under tema kulturforståelse og -sensitivitet. Dette er noe morgendagens helsearbeidere vil måtte forholde seg til i mye større grad enn til nå.

For de som er involvert $i$ utdanning av ambulansepersonell, vil boken være nyttig, tross sine svakheter og drøye pris.

\section{Guttorm Brattebø}

Akuttmedisinsk seksjon Kirurgisk serviceklinikk

Haukeland universitetssykehus

\section{Obligatorisk «pensum» for alle leger i Nord-Norge}

Anni Margaret Henriksen

\section{Å stoppe blod}

Fortellinger om læsing, helbredelse, hjelpere og varsler. 285 s. Oslo: Cappelen Damm, 2010. Pris NOK 329

ISBN 978-82-02-31514-6

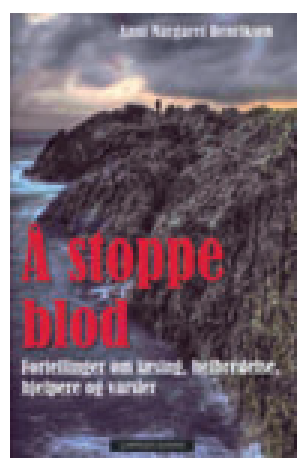

Forfatteren angir $i$ forordet at hun selv har «egne erfaringer med å stoppe blod og holde en kniv av stål mot et blødende sår». Hun er tydeligvis oppvokst $\mathrm{i}$ en kultur hvor de fenomenene hun beskriver, var vanlige, og fremstår til tider nærmest som en «forkynner». Likevel sitter man igjen med følelsen av at store deler av innholdet ikke ville vært tilgjengelig for offentligheten uten dette innenfraperspektivet.

Forfatteren er sykepleier og antropolog og strever enkelte steder med å bestemme seg for om dette er et vitenskapelig arbeid eller en dokumentarbok. Hun kan med rette anklages for ikke å ha den tilstrekkelige avstanden til stoffet, og man får den forståelsen at hun gjerne vil bruke det innsamlede stoffet i vitenskapelig arbeid senere. Jeg vil klart anbefale at den leses som en dokumentarisk skildring, så får fremtiden vise hva forfatteren velger å gjøre med hensyn til vitenskapelig bearbeiding av dette interessante stoffet.

Boken leveres i hardback uten tabeller, figurer og stikkordregister. Språket fremstår noe uferdig, men innholdet er lett tilgjengelig for lesere også utenfor den medisinske eller antropologiske profesjonen. Forfatteren angir ingen spesifikk målgruppe, men den bør etter min mening være pålagt lesing for enhver som tenker på å stå i et behandlingsforhold til mennesker i Nord-Norge. Selv sier forfatteren at hensikten er «å synliggjøre hvordan mange nordnorske kvinner og menn praktiserer sin religiøse tro i dagliglivet».

Temaene er presentert som 19 kapitler med underavsnitt. De første 11 beskriver den geografiske, religiøse og kulturelle bakgrunnen for både læsing, helbredelse, hjelp og varsling. De gir et fascinerende innblikk i en verden få mennesker utenfor miljøet selv kjenner særlig til. Forfatteren beskriver fenomener som har det fellestrekket at de hevder å nyttiggjøre seg kraften i Guds ord både i møte med hverdagens helseproblemer og daglig- og yrkeslivets risikosituasjoner. Denne bakgrunnskunnskapen er svært viktig dersom man skal kommunisere om sykdom og helse med store deler av den nordnorske befolkningen.

I resten av boken får man en rekke eksempler på mennesker som har opplevd å få hjelp i forbindelse med både sykdom, skader og ulykker. Dersom ikke flere av historiene var datobelagte, ville man umiddelbart tro at dette var historier fra en forgangen tid. Forfatteren dokumenterer imidlertid at slike hendelser rapporteres helt inn i vår egen tid.

Hendelsene som beskrives, vil ikke passe inn $\mathrm{i}$ et moderne vitenskapelig forklaringsparadigme, det vil være lett for skeptikere å avfeie dem som overtro eller tilfeldigheter. Læsing og blodstopping er imidlertid en vesentlig del av hjelpeapparatet befolkningen i Nord-Norge benytter seg av. Selv på Universitetssykehuset Nord-Norge var man i 1970- og 80-årene ikke fremmed for å kontakte blodstoppere hvis det forekom blødninger som var vanskelige å kontrollere (1).

Det viktigste med denne boken er at helsepersonell får en påminnelse om hvor viktig det er å skaffe seg en forståelse for den konteksten pasientene befinner seg $\mathrm{i}$. Over hele landet opererer mennesker innenfor flere kontekster samtidig. Fortellingene viser til fulle hvor dramatisk kontrastfylt slike kontekster kan være i møte med den vestlige skolemedisinen. 